\title{
Uji Efektivitas Antibakteri Perasan Jus Buah Nanas (Ananas comosus) Terhadap Pertumbuhan Isolat Bakteri Plak Gigi di Puskesmas Kecamatan Tanah Abang Periode April 2017
}

\author{
MITTA NURFITRI SARIDEWI ${ }^{1}$, MEISKHA BAHAR ${ }^{2}$, ANISAH $^{3}$ \\ ${ }^{1}$ Program Studi Sarjana Kedokteran, Fakultas Kedokteran, UPN Veteran Jakarta \\ Jl. RS Fatmawati, Pondok Labu, Jakarta Selatan. 12450 \\ ${ }^{2}$ Departemen Mikrobiologi, Fakultas Kedokteran, UPN Veteran Jakarta \\ Jl. RS Fatmawati, Pondok Labu, Jakarta Selatan. 12450 \\ ${ }^{3}$ Departemen Medical Unit, Fakultas Kedokteran, UPN Veteran Jakarta \\ Jl. RS Fatmawati, Pondok Labu, Jakarta Selatan. 12450 \\ Email: mittansd@gmail.com
}

Received 2 October 2017; Received in revised form 17 January 2018;

Accepted 2 February 2018; Available online 3 February 2018

\begin{abstract}
Dental caries or commonly known as "Tooth Decay" is one of the most common infection on human. Dental caries begins by the formation of dental plaque and it is a multifactorial disorder. One of the efforts to prevent the formation of dental caries is by utilizing plants which contain antibacterial substance. Pineapple contains bromelain, saponin, flavonoid, and tannin enzymes which functions as antibacteria. This research aimed to discover the antibacterial effectiveness of pineapple juice toward the isolate growth of dental plaque bacteria by using three different pineapple juice concentrations $(25 \%, 50 \%$, and $75 \%)$. The method was experimental by using dental bacteria isolate from a patient of Dental and Oral Clinic in Puskesmas Kecamatan Tanah Abang. The result shows that the higher concentration shows the bigger inhibition zone diameter formed around the plate's paper. Consequently in concentrations of $25 \%, 50 \%$, and $75 \%$, each has its own inhibition zone rate as much as 2,90 $\mathrm{mm}$ (weak); 3,89 $\mathrm{mm}$ (weak); and 5,89 $\mathrm{mm}$ (moderate).
\end{abstract}

Keywords: bromelain, dental plaque bacteria isolate, pineapple (Ananas comosus)

\section{INTISARI}

Karies gigi atau yang dikenal sebagai "gigi berlubang" merupakan salah satu penyakit yang sering terjadi pada masyarakat. Penyakit karies gigi didahului dengan terbentuknya plak gigi dan merupakan penyakit multifaktorial. Usaha untuk mencegah karies gigi secara alami yaitu dengan menggunakan tumbuhan yang mengandung senyawa antibakteri. Tanaman nanas mengandung enzim bromelain, saponin, flavonoid dan tanin yang berkhasiat sebagai antibakteri. Penelitian ini bertujuan untuk mengetahui efektivitas antibakteri dari perasan jus buah nanas terhadap pertumbuhan isolat bakteri plak gigi menggunakan tiga jenis konsentrasi perasan jus buah nanas $(25 \%, 50 \%$ dan $75 \%)$. Metode penelitian adalah eksperimental dengan menggunakan isolat bakteri plak gigi dari pasien Poli Gigi dan Mulut di Puskesmas Kecamatan Tanah Abang. Hasil analisis menunjukkan semakin tinggi konsentrasi perasan jus buah nanas yang diuji, maka akan semakin besar juga diameter zona hambat yang terbentuk di sekeliling kertas cakram. Pada konsentrasi 25\%, 50\%, dan 75\%, masing-masing memiliki rata-rata zona hambat sebesar 2,90 mm (lemah); 3,89 mm (lemah); dan 5,89 $\mathrm{mm}$ (sedang).

Kata kunci: bromelain, isolat bakteri plak gigi, Nanas (Ananas comosus)

\section{PENDAHULUAN}

Karies gigi atau yang sebagai gigi berlubang, merupakan penyakit yang dapat menyerang semua umur di dunia. Penyakit karies gigi didahului dengan terbentuknya plak gigi dan merupakan penyakit multifaktorial, 
meliputi faktor utama yaitu gigi, mikroorganisme, karbohidrat dan waktu. Beberapa contoh bakteri yang banyak ditemukan dalam plak gigi adalah Streptococcus sanguis, S. mutans. Lactobacillus, Staphylococcus aureus, dan (Kidd and Bechal, 2005).

Tingkat prevalensi plak gigi di Indonesia terbilang tinggi hingga mencapai 70-80\%. Selain mengurangi estetika, jika terjadi penumpukan plak gigi secara berkala dapat menimbulkan karies gigi dan peradangan gusi (Houwink $d k k$., 2000; Wilson, 2004). Sesuai data global WHO (2008), 5 negara di Asia yang memiliki indeks DMFT tinggi adalah India 91,84\%, Thailand 89,6\%, Korea 53,69\%, Indonesia $12,70 \%$ dan Maldives 7,58\%.

Di Indonesia terjadi peningkatan prevalensi terjadinya karies gigi pada penduduk Indonesia dibandingkan tahun 2007 lalu, dari 43,4\% (2007) menjadi 53,2\% (2013) (Riskesdas, 2007; Riskesdas, 2013). Untuk prevalensi karies gigi berdasarkan provinsi terdata bahwa hampir semua provinsi di Indonesia mengalami kenaikan prevalensi karies dari tahun 2007 ke tahun 2013, lima provinsi yang mempunyai jumlah karies melebihi angka nasional yaitu Sulawesi Selatan 36,2\%, Kalimantan Selatan 36,1\%, Yogyakarta 32,1\%, DKI Jakarta 29,1\%, Jawa Barat 28\% dan Jawa Timur 27,2\% (Riskesdas, 2013).

Dari data Riskesdas Provinsi DKI Jakarta tahun 2013 prevalensi penduduk yang mempunyai masalah gigi-mulut dalam 12 bulan terakhir adalah $29,1 \%$. Kabupaten/Kota dengan masalah gigi-mulut tinggi adalah Jakarta Barat (18,8\%), Kepulauan Seribu (20,2\%) dan Jakarta Pusat (26,7\%). Salah satu Puskesmas di Jakarta Pusat yang memiliki pasien karies cukup tinggi adalah Puskesmas Kecamatan Tanah Abang dengan jumlah pasien yang datang ke poli gigi dan mulut pada tahun 2015 sebesar 1.921 dan pada tahun 2016 meningkat menjadi 2.379 pasien dan 1.903 pasien datang dengan keluhan akibat karies gigi (Puskesmas Kec. Tanah Abang, 2016; Riskesdas, 2013). Usaha untuk mencegah karies gigi secara alami yaitu dengan menggunakan antibakteri dari tumbuhan. Saat ini telah banyak dikembangkan anti bakteri dengan bahan dasar tumbuhan yang diyakini mempunyai khasiat antibakteri dengan efek samping minimal. Salah satu tumbuhan yang diketahui dapat membantu menjaga kesehatan gigi dan mulut dan mudah didapat di Indonesia adalah buah nanas. Daun, buah, bonggol, batang, dan akar nanas mengandung enzim bromelain, saponin, flavonoid, dan tanin (Rakhmanda, 2008; Nurhidayah $d k k ., 2013$ ).

Enzim bromelain merupakan kumpulan enzim protease yang dapat mencegah perlekatan bakteri pada gigi dan dapat melisiskan sel bakteri penyebab karies gigi (Allaker and Douglas, 2009; Cahyono, 2011). Nanas juga mengandung saponin yang dapat mengganggu kestabilan membran sel bakteri. Selain itu, terdapat tanin dan flavonoid yang dapat menghambat sintesis dinding sel bakteri, mengurangi rasa sakit dan pembengkakan karena luka atau operasi (Cushnie and Lamb, 2005).

Penelitian Makalew $d k k$. (2016), uji efek antibakteri air perasan daging buah nanas (Ananas comosus) terhadap bakteri Klebsiella pneumonia dan penelitian Rakhmanda (2008) yang menguji efek antibakteri jus nanas terhadap bakteri $S$. mutans, menunjukkan bahwa air perasan daging buah nanas yang dibuat dengan cara di jus mempunyai efek sebagai antibakteri dengan cara menghambat pertumbuhan bakteri pada konsentrasi $25 \%$ dan membunuh bakteri pada konsentrasi $100 \%$. Berdasarkan latar belakang tersebut, peneliti melakukan uji efektivitas antibakteri perasan jus buah nanas konsentrasi 25\%, 50\%, dan $75 \%$ terhadap pertumbuhan isolat bakteri plak gigi di Puskesmas Kecamatan Tanah Abang.

\section{METODE}

Penelitian ini dilakukan di Laboratorium Mikrobiologi Fakultas Kedokteran Universitas Pembangunan Nasional Veteran Jakarta. Jumlah sampel plak gigi yang diambil dari pasien di Poli Gigi dan Mulut di Puskesmas Kec. Tanah Abang sebanyak 25, dengan kriteria inklusi laki-laki dan perempuan usia 25-45 tahun dan kriteria eksklusi adalah 
mengkonsumsi antibiotik kurang dari 6 bulan sebelum perlakuan, mengalami infeksi di sekitar rongga mulut, merokok, dan menggunakan kontrasepsi hormonal.

Penghitungan besar pengulangan dari tiap kelompok perlakuan ditentukan dengan menggunakan rumus Federer. Kelompok perlakuan berjumlah lima yaitu perasan jus buah nanas konsentrasi 25\%, 50\% dan $75 \%$ dan dua kelompok kontrol, yaitu satu kelompok kontrol positif berupa antibiotik dan satu kelompok kontrol negatif berupa akuades. Rumus Federer: $(\mathrm{n}-1)(\mathrm{t}-1) \geq 15$ (Dahlan, 2011). Perlakuan terhadap isolat plak gigi:

$$
\begin{aligned}
& (\mathrm{n}-1)(\mathrm{t}-1) \geq 15 \rightarrow(\mathrm{n}-1)(5-1) \geq 15 \\
& \rightarrow(\mathrm{n}-1)(4) \geq 15 \rightarrow 4 \mathrm{n} \geq 15+4 \\
& \rightarrow \mathrm{n} \geq 19 / 4 \rightarrow \mathrm{n} \geq 4,75->5
\end{aligned}
$$

Keterangan:

$\mathrm{n}=$ jumlah ulangan;

$\mathrm{t}=$ jumlah kelompok perlakuan dan kelompok kontrol (5)

Berdasarkan perhitungan di atas, maka tiap kelompok percobaan dilakukan pengulangan sebanyak lima kali.

Pengambilan sampel pada pasien karies. Subjek diseleksi berdasarkan kriteria inklusi dan eksklusi, setelah itu diberikan inform consent kepada pasien yang akan diambil sampel plak gigi. Setelah plak diambil oleh dokter gigi menggunakan swab steril, dimasukkan ke dalam tabung berisi $\mathrm{NaCl}$ sebagai media transport, kemudian dimasukkan dalam ice box dan dibawa ke laboratorium Mikrobiologi FK UPN Veteran Jakarta.

Penanaman isolat bakteri plak gigi. Sampel isolat bakteri plak gigi dikultur ke nutrient agar. Setelah itu diinkubasi selama $1 \times 24$ jam dalam inkubator pada suhu $37^{\circ} \mathrm{C}$. Lalu diamati pertumbuhan bakteri tersebut.

Pembuatan perasan jus buah nanas. Bahan uji adalah perasan jus buah nanas Cayenne yang dikirim dari Kota Subang, Provinsi Jawa Barat pada waktu seminggu sebelum masa panen. Buah nanas dikupas dan dicuci, lalu ditimbang hingga mencapai 200 gram. Daging buah nanas yang diperoleh selanjutnya dipotong kecil-kecil dan dimasukkan ke dalam blender. Jus yang dihasilkan kemudian diperas dan disaring menggunakan kain katun dan dimasukkan ke dalam tabung Erlenmeyer, selanjutnya ditutup dengan alumunium foil. Air perasan tersebut merupakan air perasan daging buah nanas dengan konsentrasi 100\% (Makalew dkk., 2016). Konsentrasi yang digunakan diperoleh dengan rumus:

$$
\mathrm{M} 1 . \mathrm{V} 1=\mathrm{M} 2 . \mathrm{V} 2
$$

Keterangan:

M1 = molaritas sebelum pengenceran

$\mathrm{M} 2=$ molaritas setelah pengenceran

$\mathrm{V} 1=$ volume sebelum pengenceran

$\mathrm{V} 2$ = volume setelah pengenceran

Masing-masing konsentrasi dibuat dengan volume $10 \mathrm{ml}$

Sebanyak 2,5 $\mathrm{ml}$ perasan jus buah nanas dari tabung Erlenmeyer diambil menggunakan spuit dan dimasukkan ke dalam tabung reaksi lalu ditambahkan akuades steril 7,5 $\mathrm{ml}$ hingga volume ditabung mencapai $10 \mathrm{ml}$, air perasan tersebut merupakan konsentrasi $25 \%$. Sebanyak $5 \mathrm{ml}$ perasan jus buah nanas ditambahkan $5 \mathrm{ml}$ akuades steril yang merupakan konsentrasi 50\%. Selanjutnya 7,5 $\mathrm{ml}$ perasan jus buah nanas ditambahkan $2,5 \mathrm{ml}$ akuades steril yang merupakan konsentrasi $75 \%$.

Persiapan bakteri uji. Pembuatan suspensi isolat bakteri plak gigi dengan larutan $\mathrm{NaCl}$ 0,9\% sampai terbentuk kekeruhan yang mencapai standar 0,5 McFarland. Suspensi isolat bakteri plak gigi dikultur ke media nutrient agar.

Uji efek antibakteri perasan jus buah nanas. Pengujian ini menggunakan metode difusi cakram dengan media nutrient agar sebanyak 125 cawan petri, 625 buah kertas cakram. Media nutrient agar bagian belakang cawan petri dibagi menjadi 5 dan diberi kode menggunakan spidol selama 30 menit kertas cakram pada konsentrasi perasan daging buah nanas $(25 \%, 50 \%, 75 \%)$, pada aquades steril dan antibiotik klindamisin. Selanjutnya media nutrient agardiinkubasi pada suhu $37^{\circ} \mathrm{C}$ selama 24 jam.

Analisis Data. Analisis data hasil penelitian ini dilakukan dengan uji KruskalWallis dan kemudian dilanjutkan dengan uji Post Hoc (Mann-Whitney) untuk mengetahui perbedaan setiap kelompok (Dahlan, 2011). 
HASIL

Hasil uji efektifitas antibakteri perasan jus buah nanas yang memakai berbagai konsentrasi yaitu 25\%, 50\%, dan 75\% terhadap pertumbuhan isolat bakteri plak gigi adalah sebagai berikut:

Tabel 1. Rerata hasil pengukuran diameter zona hambat

\begin{tabular}{cc}
\hline Konsentrasi & $\begin{array}{c}\text { Rata-Rata Diameter Zona Hambat Isolat } \\
\text { Bakteri Plak Gigi (mm) }\end{array}$ \\
\hline $\mathbf{2 5 \%}$ & 2,90 \\
\hline $\mathbf{5 0 \%}$ & 3,89 \\
\hline $\mathbf{7 5 \%}$ & 5,89 \\
\hline Kontrol Positif & 19,73 \\
\hline Kontrol Negatif & 0 \\
\hline
\end{tabular}

Pada Tabel 1 dapat dilihat bahwa kelompok kontrol negatif tidak membentuk zona hambat. Kelompok perasan jus buah nanas dengan konsentrasi $25 \%, 50 \%$, dan $75 \%$ memperlihatkan adanya zona hambat. Hal ini menunjukkan bahwa perasan jus buah nanas memiliki efektivitas antibakteri terhadap pertumbuhan isolat bakteri plak gigi. Pada konsentrasi $25 \%, 50 \%$, dan $75 \%$, masingmasing memiliki rerata zona hambat terhadap pertumbuhan isolat bakteri plak gigi sebesar 2,90 mm, 3,89 mm, dan 5,89 mm. Sedangkan pada kontrol positif mempunyai zona hambat sebesar $19,73 \mathrm{~mm}$.

Tabel 2. Hasil uji Mann-Whitney data hasil pengukuran diameter zona hambat perasan jus buah nanas terhadap pertumbuhan isolat bakteri plak gigi

\begin{tabular}{|c|c|c|c|}
\hline Kelompok & & Nilai $p$ value diperoleh & Keterangan \\
\hline \multirow[t]{2}{*}{ Kontrol Positif } & Kontrol Negatif & 0,000 & $\mathrm{p} \leq 0,05$ \\
\hline & $\begin{array}{l}\text { Perasan Jus Buah Nanas } \\
\text { Konsentrasi } 25 \%\end{array}$ & 0,000 & $\mathrm{p} \leq 0,05$ \\
\hline \multirow[t]{2}{*}{ Kontrol Negatif } & $\begin{array}{c}\text { Perasan Jus Buah Nanas } \\
\text { Konsentrasi 50\% } \\
\text { Perasan Jus Buah Nanas } \\
\text { Konsentrasi 75\% } \\
\text { Perasan Jus Buah Nanas } \\
\text { Konsentrasi 25\% }\end{array}$ & $\begin{array}{l}0,000 \\
0,000 \\
0,000\end{array}$ & $\begin{array}{l}\mathrm{p} \leq 0,05 \\
\mathrm{p} \leq 0,05 \\
\mathrm{p} \leq 0,05\end{array}$ \\
\hline & $\begin{array}{c}\text { Perasan Jus Buah Nanas } \\
\text { Konsentrasi } 50 \%\end{array}$ & 0,000 & $\mathrm{p} \leq 0,05$ \\
\hline $\begin{array}{c}\text { Perasan Jus Buah } \\
\text { Nanas Konsentrasi } \\
25 \%\end{array}$ & $\begin{array}{c}\text { Perasan Jus Buah Nanas } \\
\text { Konsentrasi } 75 \% \\
\text { Perasan Jus Buah Nanas } \\
\text { Konsentrasi 50\% } \\
\text { Perasan Jus Buah Nanas } \\
\text { Konsentrasi 75\% }\end{array}$ & $\begin{array}{l}0,000 \\
0,001 \\
0,000\end{array}$ & $\begin{array}{l}\mathrm{p} \leq 0,05 \\
\mathrm{p} \leq 0,05 \\
\mathrm{p} \leq 0,05\end{array}$ \\
\hline $\begin{array}{c}\text { Perasan Jus Buah } \\
\text { Nanas Konsentrasi } \\
50 \%\end{array}$ & $\begin{array}{l}\text { Perasan Jus Buah Nanas } \\
\text { Konsentrasi } 75 \%\end{array}$ & 0,000 & $\mathrm{p} \leq 0,05$ \\
\hline
\end{tabular}

Hasil analisa uji Mann-Whitney menunjukkan bahwa antar keseluruhan kelompok memiliki nilai $p$ value lebih kecil dari $0,05(\mathrm{p} \leq 0,05)$ sehingga $\mathrm{H} 1$ diterima, yang artinya terdapat perbedaan bermakna zona hambat perasan jus buah nanas terhadap pertumbuhan isolat bakteri plak gigi pada semua kelompok.

\section{PEMBAHASAN}

Hasil penelitian yang telah dilakukan dengan rerata hasil pengukuran diameter zona 
hambat yang dihasilkan perasan jus buah nanas terhadap pertumbuhan isolat bakteri plak gigi di Puskesmas Kecamatan Tanah Abang tercantum dalam Tabel 1. Untuk mengetahui kelompok perlakuan yang memiliki perbedaan bermakna tersebut, maka selanjutnya dilakukan analisis dengan uji Mann-Whitney. Hasil uji Mann-Whitney menunjukkan terdapat perbedaan bermakna antara masing-masing kelompok konsentrasi 25\%, 50\%, 75\%, kontrol positif dan kontrol negatif.

Kekuatan daya antibakteri dibagi menjadi empat kategori menurut Davis dan Stout (1971) yaitu menghambat lemah $(<5 \mathrm{~mm})$, sedang $(5-10 \mathrm{~mm})$, kuat $(10-20 \mathrm{~mm})$, dan sangat kuat $(>20 \mathrm{~mm})$. Pada penelitian ini, daya hambat perasan jus buah nanas pada konsentrasi $25 \%(2,90 \mathrm{~mm})$ dan $50 \%(3,89$ $\mathrm{mm}$ ) termasuk kategori lemah dan daya hambat perasan jus buah nanas pada konsentrasi $75 \%(5,89 \mathrm{~mm})$ termasuk ke dalam kategori sedang. Berdasarkan hasil tersebut, dapat diketahui bahwa semakin tinggi konsentrasi perasan jus buah nanas yang diuji, maka akan semakin besar juga diameter zona hambat yang terbentuk di sekeliling kertas cakram.

Hal ini sejalan dengan penelitian Rahkmanda (2008) yang memperlihatkan peningkatan efek antibakteri dari konsentrasi $25 \%$ dan $50 \%$ jus nanas dalam menghambat pertumbuhan bakteri $S$. mutans dan pada konsentrasi $100 \%$ jus nanas dapat membunuh bakteri $S$. mutans. Hasil penelitian ini juga sesuai dengan penelitian Makalew $d k k$. (2016) yang menunjukkan hasil bahwa perasan jus nanas meningkat efek antibakterinya sesuai dengan peningkatan konsentrasi, yaitu 25\% (1,67 mm), $50 \%$ (1,12 mm), dan 75\% (1,76 $\mathrm{mm})$ terhadap pertumbuhan bakteri Klebsiella pneumonia.

Hasil pengukuran zona hambat yang meningkat sejalan dengan peningkatan konsentrasi perasan jus buah nanas ini sesuai dengan penelitian Parwata dan Dewi (2008), bahwa efektivitas suatu antibakteri dipengaruhi oleh konsentrasi zat tersebut. Hal ini berarti semakin tinggi konsentrasi perasan jus buah nanas, maka semakin tinggi juga kandungan senyawa bioaktif yang mempunyai efek antibakteri terhadap pertumbuhan isolat bakteri plak gigi (Pratiwi, 2009).

Efek antibakteri ini diduga terjadi karena nanas memiliki 4 senyawa bioaktif yaitu, enzim bromelain, saponin, tanin, dan flavonoid. Senyawa bioaktif nanas yang pertama yaitu enzim bromelain, yang dapat menurunkan tegangan permukaan dinding bakteri sehingga menyebabkan lisis bakteri plak gigi dan dapat memecah ikatan protein glutamin-alanin yang digunakan bakteri plak gigi sebagai media perlekatan, sehingga dapat menghambat perlekatan antara bakteri plak gigi dengan pelikel (Kongsuwan et al., 2009; Angraeni dan Rahmawati, 2012). Senyawa bioaktif yang kedua yaitu saponin, saponin dalam nanas merupakan senyawa semipolar larut dalam lipid dan air sehingga mudah menyerap ke dalam membran sel bakteri plak gigi dan mengganggu kestabilan membran sel bakteri plak gigi, hal ini menyebabkan sitoplasma bocor keluar dari sel bakteri dan mengakibatkan kematian sel bakteri plak gigi (Cushine and Lamb, 2005). Senyawa bioaktif yang ketiga pada nanas adalah tanin, yang mempunyai daya antibakteri dengan cara menghambat enzyme reverse transkriptase dan DNA topoisomerase sehingga sel bakteri plak gigi tidak dapat terbentuk. Senyawa bioaktif yang keempat yaitu flavonoid yang bekerja dengan menghambat pertumbuhan isolat bakteri plak gigi dengan mekanisme menumpuk basa asam nukleat bakteri plak gigi sehingga menghambat pembentukan DNA dan RNA bakteri plak gigi (Cushine and Lamb, 2005; Jo et al., 2005; Au et al., 2001).

\section{KESIMPULAN}

Berdasarkan penelitian yang telah dilakukan, maka dapat disimpulkan sebagai berikut:

1. Efektivitas antibakteri perasan jus buah nanas terhadap pertumbuhan isolat bakteri plak gigi pada konsentrasi $25 \%$ memiliki rata-rata hasil pengukuran zona hambat sebesar 2,90 mm yang termasuk kategori lemah.

2. Efektivitas antibakteri perasan jus buah nanas terhadap pertumbuhan isolat bakteri plak gigi pada konsentrasi 50\% memiliki 
rata-rata hasil pengukuran zona hambat sebesar 3,89 mm yang termasuk kategori lemah.

3. Efektivitas antibakteri perasan jus buah nanas terhadap pertumbuhan isolat bakteri plak gigi pada konsentrasi $75 \%$ memiliki rata-rata hasil pengukuran zona hambat sebesar 5,89 $\mathrm{mm}$ yang termasuk kategori sedang.

\section{DAFTAR PUSTAKA}

Allaker RP and Douglas CWI. 2009. Novel Anti-Microbial Therapies for Dental Plaque-Related Diseases. International Journal of Antimicrobial Agents. vol 33(1): $\quad 8-13$. DOI: https://doi.org/10.1016/j.ijantimicag.2008 .07 .014 .

Angraeni DP dan Rahmawati AD. 2012. Efektivitas daya antibakteri ekstrak kulit nanas (Ananas comosus (L) Merr) terhadap pertumbuhan Streptococcus mutans. [Skripsi]. Yogyakarta: Pendidikan Dokter Gigi Universitas Muhammadiyah Yogyakarta.

Au TK, Lam TL, Ng TB, Fong WP, Wan DCC. 2001. A comparison of HIV-1 integrase inhibition by aqueous and methanol extracts of Chinese medicinal herbs. Life Sciences. vol 68(14): 1687-1694. DOI: https://doi.org/10.1016/S00243205(01)00945-6.

Cahyono B. 2011. Buku Terlengkap Budidaya Nanas secara Komersial. Jakarta: Pustaka Mina.

Cushnie TPT and Lamb AJ. 2005. Antimicrobial activity of flavonoids. International Journal of Antimicrobial Agents. vol 26(5): 343-356. DOI: https://doi.org/10.1016/j.ijantimicag.2005 .09 .002 .

Dahlan MS. 2011. Statistik Untuk Kedokteran dan Kesehatan Edisi 5. Jakarta: Salemba Medika

Davis WW and Stout TR. 1971. Disc Plate Method of Microbiological Antibiotic Assay. Applied and Enviromental Microbiology. vol. 22 (4): 666-670.

Houwink, Dirks B, Winchel C. 2000. Ilmu Kedokteran Gigi Pencegahan.
Yogyakarta: Gadjah Mada University Press.

Jo JY, de Mejia EG, Lila MA. 2005. Effects of Grape Cell Culture Extracts on Human Topoisomerase II Catalytic Activity and Characterization of Active Fractions. $J$. Agric. Food Chem, vol 53 (7): 2489-2498. DOI https://doi.org/10.1021/jf048524w.

Kidd EAM dan Bechal SJ. 2005. Dasar-dasar Karies: Penyakit dan Penanggulangannya. Jakarta: EGC.

Kongsuwan A, Suthiluk P, Theppakorn T, Srilaong V and Setha S. 2009. Bioactive compounds and antioxidant capacities of phulae and nanglae pineapple. As. J. Food Ag-Ind. vol 2, Special Issue: S44-S50.

Nurhidayah, Masriany, Masri M. 2013. Isolasi dan Pengukuran Aktivitas Enzim Bromelin dari Ekstrak Kasar Batang Nanas (Ananas comosus) Berdasarkan Variasi pH. Biogenesis. vol 1(2): 116-122. DOI: https://doi.org/10.24252/bio.v1i2.457.

Makalew MAJ, Nangoy E, Wowor PM. 2016. Uji Efek Antibakteri Air Perasan Daging Buah Nanas (Ananas comosus (L.) merr) Terhadap bakteri Klebsiella pneumonia. Jurnal e-Biomedik. vol 4(1): 1-6.

Parwata IMOA dan Dewi PFS. 2008. Isolasi dan Uji Aktivitas Antibakteri Minyak Atsiri Dari Rimpang Lengkuas (Alpinia galanga L.). Jurnal Kimia (Journal of Chemistry). vol 2(2): 100-104.

Pratiwi I. 2009. Uji Antibakteri Ekstrak Kasar Daun Acalypha indica Terhadap Bakteri Salmonella choleraesuis dan Salmonella typhimurium. [Skripsi]. Surakarta: Jurusan Biologi FMIPA Universitas Sebelas Maret.

Puskesmas Kecamatan Tanah Abang. 2016. Laporan Jumlah Pasien Pada Poli Gigi dan Mulut Tahun 2016. Jakarta Pusat.

Rakhmanda AP. 2008. Perbandingan Efek Antibakteri Jus Nanas (Ananas comosus L. merr) Pada Berbagai Konsentrasi Terhadap Streptococcus mutans. [KTI]. Semarang: Fakultas kedokteran, Universitas Diponegoro.

Riskesdas. 2007. Hasil Riset Kesehatan Dasar 2007. Jakarta: Badan Penelitian dan 
Pengembangan Kesehatan Kementerian Kesehatan RI. www.depkes.go.id. Diakses September 2017.

Riskesdas. 2013. Hasil Riset Kesehatan Dasar 2013. Jakarta: Badan Penelitian dan Pengembangan Kesehatan Kementerian Kesehatan RI. www.depkes.go.id. Diakses September 2017.

Wilson M. 2004. Lethal Photosensitisation of Oral Bacteria and Its Potential Application in the Photodynamic Therapy of Oral Infections. Photochem. Photobiol. Sci. vol 5(3): 412-418.

DOI: https://doi.org/10.1039/B211266C.

World Health Organization. 2008. Oral Health Information Systems 2008. http://www.who.int. diakses Oktober 2017. 